\title{
ANALISIS PENGARUH VARIASI FRAKSI VOLUME TERHADAP KEKUATAN TARIK BAHAN KOMPOSIT POLIESTER DENGAN FILLER ALAMI SERABUT KELAPA MERAH
}

\author{
Alwiyah Nurhayati
}

\begin{abstract}
Abstrak
Serabut kelapa (cocofiber) adalah satu serat alam yang memiliki prospek yang cukup baik, dimana pengolahannya masih belum banyak dilakukan atau ditangani dengan baik, sehingga tidak dimanfaatkan secara optimal. Serabut kelapa yang dikombinasikan dengan resin poliester sebagai matriks akan dapat menghasilkan komposit alternatif untuk aplikasi struktural. Preparasi spesimen awal meliputi pemotongan serat kelapa sepanjang $2 \mathrm{~cm}$, pencampuran poliester dan serabut kelapa dengan variasi fraksi volume serabut kelapa 1\%, 2\% dan 3\%, dan pencetakan spesimen sesuai dengan standar uji tarik. Dari hasil pengujian didapatkan kekuatan tarik tertinggi pada spesimen dengan fraksi volume 3\% yang memiliki tegangan $28 \mathrm{MPa}$ dan regangan 0.027, modulus elastisitas $1027.523 \mathrm{MPa}$. Spesimen dengan fraksi volume $2 \%$ mempunyai tegangan $22 \mathrm{MPa}$ dan regangan 0.027 pada komposit dengan modulus elastisitas sebesar 807.339 MPa. Spesimen denganl fraksi volume 1\% mempunyai tegangan 20.4 MPa dan regangan 0.032 dengan modulus elatisitas sebesar $623.558 \mathrm{MPa}$.
\end{abstract}

Kata kunci : serabut kelapa, resin poliester, fraksi volume, kekuatan tarik. 


\section{PENDAHULUAN}

Penggunaan bahan komposit dengan filler serat alam mulai dikenal dalam bidang industri. Bahan yang ramah lingkungan, mampu didaur ulang, serta mampu dihancurkan sendiri oleh alam merupakan tuntutan teknologi sekarang ini. Salah satu bahan yang diharapkan mampu memenuhi hal tersebut adalah bahan komposit dengan filler serat alam. Serabut kelapa merupakan serat alam yang memiliki prospek yang cukup baik, di mana pengolahan serabut kelapa sebagai filler bahan komposit masih belum banyak dilakukan sehingga hanya menjadi limbah yang kurang bermanfaat.

Serabut kelapa memiliki sifat tahan lama, sangat ulet, kuat terhadap gesekan, tidak mudah patah, tahan terhadap air, tidak mudah membusuk, tahan terhadap jamur dan hama serta tidak dihuni oleh rayap dan tikus sehingga serat alam ini bisa menjadi alternatif filler bahan komposit, karena selain murah, ketersediaan serabut kelapa sangat berlimpah (Moncrieff, 1983).

Penelitian ini mencoba mengembangkan bahan komposit berpenguat serabut kelapa dari jenis kelapa merah dengan variasi fraksi volume serabut kelapa 1\%,2\% dan 3\% dikombinasikan dengan bahan matriks poliester Yukalac C108yang diharapkan dapat menjadi material alternatif serta meningkatkan nilai ekonomis dari serabut kelapa.

\section{TINJAUAN PUSTAKA}

Material komposit merupakan suatu jenis bahan baru dari kombinasi dua atau lebih bahan di mana memiliki bahan dan sifat yang berbeda, dari pencampuran tersebut akan menghasilkan material komposit yang memiliki sifat mekanik dan karakteristik yang berbeda (Schwartz, 1984). Bahan komposit memiliki kelebihan antara lain berat yang lebih ringan, kekuatan yang lebih tinggi, tahan korosi dan memiliki biaya perakitan yang lebih murah karena berkurangnya jumlah komponen,kekuatannya,ketahanan terhadap pengurangan 
berat material(konstruksi ringan).Komponen utama dari bahan komposit adalah bahan pengikat (matriks) dan bahan pengisi (filler). Di dalam penelitian ini bahan komposit yang dibuat termasuk dalam jenis bahan komposit polimer. Bahan matriks yang digunakan adalah resin poliester sedangkan yang berperan sebagai bahan pengisi adalah serabut kelapa merah ditambah dengan bahan aditif katalis yang berfungsi sebagai pengeras bahan komposit yang dicetak.

Resin poliester merupakan salah satu resinpoliester termoset yang mempunyai kemampuan berikatan dengan serat alam tanpa menimbulkan reaksi dangas, oleh karena itu resinpoliester digunakan dalam penelitian ini.

Serabut kelapa terdiri dari serat dan gabus yang menghubungkan satu serat dengan serat lainnya yang merupakan bagian berharga dari sabut (Isroful, 2006). Setiap butir kelapa mengandung serat 525 gram (75\% dari serabut), dan gabus 175 gram (25\% dari serabut).

Sifat-sifat komposit dipengaruhi kuantitas serabut kelapa yang digunakan, sehingga perlu diteliti pengaruh jumlah fraksi berat serabut kelapa dalam komposit resinpoliester atau serabut kelapa terhadap fisis dan mekanisnya(Supriadi,1997).

Faktor yang mempengaruhi performa komposit antara lain adalah faktor serabut, letak serabut, panjang serabut, bentuk serabut, faktor matrik, dan katalis (Sinuhaji, 1994).

Ada dua jenis komposit serabut berdasarkan susunan dan panjang serat yaitu sebagai komposit serabut pendek yang memiliki panjang 20-100 mm dan komposit serabut panjang yang lebih mudah diorientasikan jika dibandingkan serabut pendek. Perbedaan serabut pendek dan serabut panjang yaitu serabut pendek dibebani secara tidak langsung dan kekuatan atau kelemahan matriks akan menentukan sifat dari produksi komposit tersebut yakni jauh lebih kecil dibandingkan dengan besaran yang terdapat pada serabut panjang yang memiliki kemampan yang tinggi (Derek Hull, 1981). 


\section{METODE EKSPERIMEN}

Langkah awal yang dilakukan dalam penelitian ini adalah melakukan uji tarik terhadap bahan matriks dan filler untuk mendapatkan data kekuatan tarik dari kedua bahan tersebut. Pengujian filler menggunakan standar pengujian ASTM D337975.

Penentuan densitas dari serabut kelapa dilakukan dengan menggunakan piknometer. Data densitas serabut kelapa merah yang didapatkan dari pengujian tersebut adalah sebesar 1,59 gr/ $\mathrm{cm} 3$.

Serabut kelapa merah disiapkan dalam bentuk potongan kecil dengan ukuran panjang $2 \mathrm{~cm}$ dan diameter 0,1 mm yang telah dibersihkan dan dikeringkan selama tiga hari. Pencampuran bahan matriks poliester Yukalac C108 dan filler serabut kelapa merah beserta katalis dilakukan sesuai dengan kadar ukuran masing-masing variasi fraksi volume $1 \%, 2 \%$, dan 3\% untuk kemudian dicetak dalam cetakan yang dibuat sesuai dengan standar uji tarik material yaitu ASTM D3039. Pada penelitian ini filler ditata secara acak.

Langkah selanjutnya adalah melakukan uji tarik dari spesimen bahan komposit dari masing-masing spesimen untuk diperoleh data kekuatan tariknya dengan menggunakan Autograph.

\section{HASIL DAN PEMBAHASAN}

\section{A. Hasil Uji Tarik Bahan Serabut Kelapa Dan Bahan Matrik (Resin poliester)}

Setelah dilakukan uji tarik pada serabut kelapa dan resin polyester, dilakukan pembuatan grafik tegangan-regangan serabut kelapa dan resin polyester sehingga dapat diketahui posisi titik elastis dan titik plastis dalam bahan-bahan tersebut seperti yang disajikan pada Grafik 4.1. 


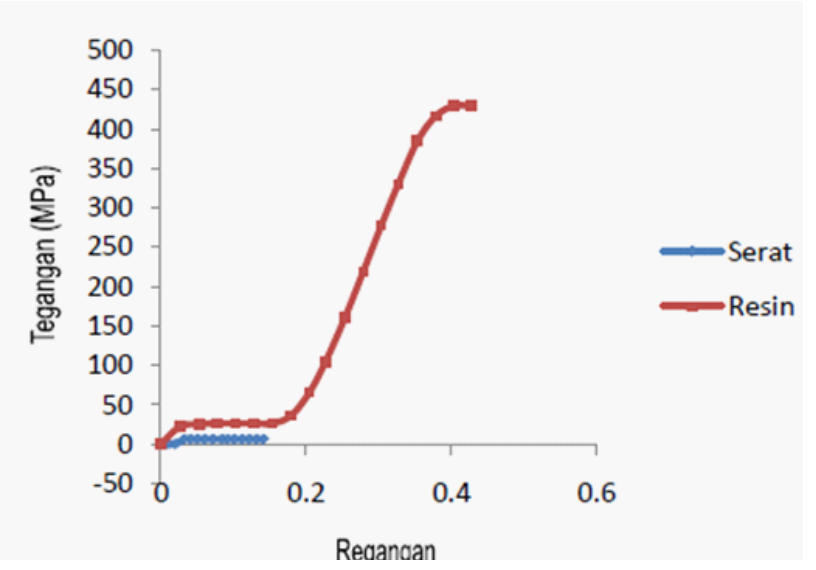

Grafik 4.1

Uji Tarik antara Serabut Kelapa Merah dengan Resin Poliester

Gambar di atas menunjukkan hubungan antara tegangan dan regangan dari resin poliester dan serabut kelapa merah pada saat di lakukan pengujian tarik pada bahan tersebut. Pada titik 0.027 MPa termasuk daerah elastisitas pada resin poliester dan pada titik $0.032 \mathrm{MPa}$ pada serat, karena pada titik tersebut regangan yang dihasilkan oleh resin poliester dan serabut kelapa lebih tinggi di bandingkan dengan regangan. Dan apabila semakin ke atas, gaya elastisitasnya semakin berkurangnya ke elastisitasnya karena kualitas massa dari serabut dan resin poliester yang berbeda dan tegangan yang di muat oleh resin poliester dan serabut tersebut semakin tinggi di banding dengan regangan yang terdapat pada serabut dan resin poliester yang ada. Keelastisitasan pada resin poliester dan serabut kelapa merah menurun dan dapat dilihat pada titik 26.4 terdapat pada resin poliester dan pada titik 6.369 MPa terdapat pada serat yang semakin naik, menyebabkan elastisitas yang terdapat pada resin poliester tersebut semakin menurun atau dapat juga di katakan bahwa semakin besarnya regangan yang terdapat pada benda maka gaya elastisitasnya semakin lama semakin menurun.

Data hasil pengujian ini digunakan sebagai dasar untuk pembuatan bahan komposit dengan variasi fraksi volume yang telah ditentukan. 
Alwiyah Nurhayati

\section{B. Hasil Uji Tarik Bahan Komposit}

\section{Tabel 4.1 \\ Hasil Tegangan Tarik Komposit (MPa)}

\begin{tabular}{|l|c|r|r|}
\hline \multirow{2}{*}{ Panjang Serabut kelapa } & \multicolumn{3}{|c|}{ Fraksi Volume } \\
\cline { 2 - 4 } & \multicolumn{1}{|c|}{$\mathbf{1 \%}$} & \multicolumn{1}{c|}{$\mathbf{2 \%}$} & \multicolumn{1}{c|}{$\mathbf{3 \%}$} \\
\hline Spesimen 1 $(\mathrm{MPa})$ & 169.323 & 147.529 & 128.583 \\
\hline Spesimen 2 $(\mathrm{MPa})$ & 107.364 & 84.309 & 92.58 \\
\hline Spesimen 3 $(\mathrm{MPa})$ & 104.387 & 117.576 & 85.939 \\
\hline Rata - Rata $(\mathrm{MPa})$ & 127.025 & 116.471 & 102.367 \\
\hline
\end{tabular}

Dari pengujian uji tarik komposit terdapat penurunan tegangan dari 127.024 MPa ke 116.471 MPa dan ke 102.367265 MPa dikarenakan oleh adanya pengaruh penambahan volume serabut kelapa.

- Penurunan tegangan tarik komposit dari volume $1 \%$ ke $2 \%$

$$
\frac{116.471-127.025}{127.025} \times 100 \%=\frac{-10.554}{127.025} \times 100 \%=-8 \%
$$

- Penurunan tegangan tarik komposit dari volume $2 \%$ ke $3 \%$

$$
\frac{102.367-127.025}{127.025} \times 100 \%=\frac{-24.658}{127.025} \times 100 \%=-19 \%
$$

- Penurunan tegangan tarik komposit dari volume $1 \%$ ke $3 \%$

$$
\frac{102.367-116.471}{116.471} \times 100 \%=\frac{-14.104}{116.471} \times 100 \%=-12 \%
$$


Dari pengujian uji tarik komposit terdapat penurunan rengangan dari fraksi volume $1 \%$ ke $2 \%$ dan ke 3\%, dimungkinkan karena belum terbentuknya ikatan antara serabut kelapa dengan resin polyester sehingga mengakibatkan penurunan rengangan yang terjadi.

- Kenaikan regangan tarik komposit dari volume $1 \%$ ke $2 \%$

$$
\frac{0.146-0.136}{0.136} \times 100 \%=\frac{0.01}{0.136} \times 100 \%=7 \%
$$

- Penurunan tegangan tarik komposit dari volume $2 \%$ ke $3 \%$

$$
\frac{0.120-0.146}{0.146} \times 100 \%=\frac{-0.026}{0.146} \times 100 \%=-17 \%
$$

- Penurunan tegangan tarik komposit dari volume $1 \%$ ke $3 \%$

$$
\frac{0.120-0.136}{0.136} \times 100 \%=\frac{-0.016}{0.30675} \times 100 \%=-5 \%
$$

Berdasarkan data yang didapatkan dari pengujian tarik spesimen, dibuat grafik perbandingan bahan komposit dari masingmasing variasi fraksi volume sebagai berikut.

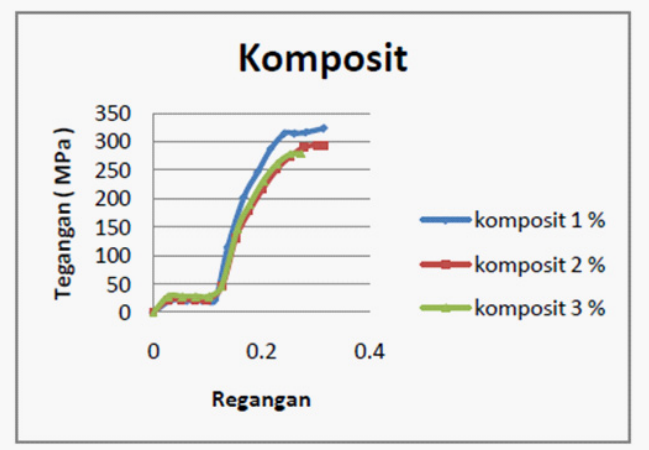




\section{Perbandingan Hasil Uji Tarik Bahan Komposit Variasi Fraksi Volume}

Dari grafik yang diperoleh di atas hasil komposit dengan fraksi volume $1 \%$ dari pengujian tarik spesimen mempunyai tegangan pada daerah elastis sebesar 20.4 MPa dan regangan 0.032 dengan modulus elastisitas sebesar $632.558 \mathrm{MPa}$. Komposit dengan fraksi volume $2 \%$ mempunyai tegangan pada daerah elastis sebesar $22 \mathrm{MPa}$ dan regangan 0.027 dengan modulus elastisitas sebesar $807.339 \mathrm{MPa}$. Komposit dengan fraksi volume $3 \%$ dari pengujian tarik terdapat modulus elastisitas yang paling tinggi yaitu pada spesimen mempunyai tegangan pada daerah elastis sebesar $28 \mathrm{MPa}$ dan regangan 0.027 dengan modulus elastisitas sebesar 1027.523 MPa.

Dari grafik yang diperoleh diatas hasil komposit perbandingan dari spesimen dengan pengujian tarik terdapat modulus elastisitas yang paling tinggi dari fraksi volume 1\%, 2\%,3\% yaitu pada komposit 3\% karena didalam memiliki tegangan pada daerah elastis sebesar $28 \mathrm{MPa}$ dan regangan sebesar 0.027 dan sedikitnya fraksi volume yang ada dengan mempunyai modulus elatisitas sebesar 1027.523 MPa. Pada komposit 3\% mempunyai daerah elastis dengan tegangan sebesar $28 \mathrm{Mpa}$ dan regangan sebesar 0.027 sedangkan daerah plastis dengan tegangan $45 \mathrm{Mpa}$ dan regangan sebesar 0.125 Sehingga dari perbandingan tersebut komposit mengalami peningkatan yang dipengaruhi adanya penambahan fraksi volume dapat menyebabkan meningkatnya nilai modulus elastisitas pada komposit. Semakin tinggi tegangan dan semakin rendah regangannya maka mempunyai modulus elastisitas yang baik. 


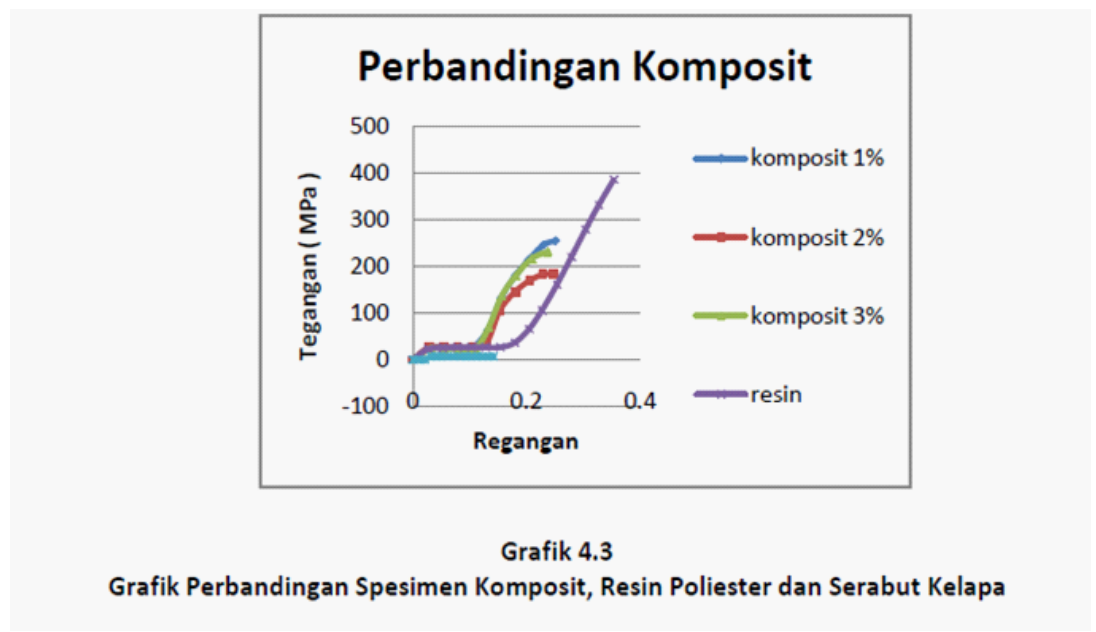

Dari grafik tersebut dapat dilihat bahwa komposit $3 \%$ lebih elastis dibandingkan dengan tiga variasi fraksi volume $1 \%$ dan $2 \%$ dengan tegangan sebesar $28 \mathrm{MPa}$ dan regangan 0.027 dan modulus elastisitas sebesar 1027.52 MPa.

Berdasarkan data hasil pengujian dapat diketahui:

1) Komposit yang telah diisi dengan serabut kelapa merah kekuatannya lebih tinggi dari kekuatan resin poliester. Dari penelitian diperoleh besarnya kekuatan tarik yaitu dari fraksi volume $1 \%$ sebesar $632.558 \mathrm{MPa}$, fraksi volume $2 \%$ sebesar $807.339 \mathrm{MPa}$, dan fraksi volume 3\% sebesar 1027.52 MPa. Maka dapat disimpulkan dari pengujian uji tarik komposit bila semakin banyak volume serabut kelapanya maka semakin tinggi kekuatannya, sedangkan bila semakin sedikit serabut maka kekuatan semakin kecil, akan tetapi bila terlalu sedikit serabut kelapa yang tidak seimbang dengan volume matriknya, maka kekuatannya juga akan melemah.

2) Pengujian komposit belum tentu membawa hasil yang baik tetapi harus melihat penyebab penurunan kekuatannya. Penurunan kekuatan tarik disebabkan oleh banyak faktor yaitu :

a. Pada pengujian penurunan kekuatan komposit disebabkan kurang seragamnya kondisi serabut kelapa merah dan ketidak ratanya campuran resin poliester murni dan serabut kelapa pada cetakan. 
b. Penurunan kekuatan komposit juga dikarenakan oleh adanya void/lubang pada komposit yang menyebabkan kerusakan yang lebih dahulu sebelum terjadi pengujian.

c. Selain itu juga karena pengaruh posisi dari serabut kelapa yang tidak saling berkaitan yang menyebabkan mudahnya retak komposit pada matriknya. Di dalam teori, panjang serabut kelapa juga mempengaruhi kekuatannya, serabut kelapa pendek kekuatannya lebih kecil dibanding serabut kelapa panjang.

d. Dan juga penurunan terjadi karena pada saat pembuatan komposit, antara resin poliester dengan serabut kelapa kurang terikat atau tercampur dengan sempurna.

\section{SIMPULAN}

Berdasarkan hasil analisa dan perhitungan dari data-data yang diperoleh dari hasil pengujian tentang pengaruh penambahan variasi fraksi volume serabut kelapa pada matrik resin poliester maka dapat diambil suatu simpulan bahwa kekuatan tarik komposit serabut kelapa - metrik resin poliester dengan penambahan variasi fraksi volume 1\%,2\%,3\% mengalami peningkatan dengan modulus elastisitas $1 \%$ sebesar $632,558 \mathrm{MPa}$, sedangkan modulus elastisitas $2 \%$ sebesar $807,339 \mathrm{MPa}$, dan pada $3 \%$ terdapat modulus elastisitas sebesar 1027,523 MPa. Dapat disimpulkan bahwa semakin besar variasi fraksi volume dapat mempengaruhi keelastisitasan benda dari komposit tersebut dikarenakan adanya perpaduan antara serabut kelapa dan resin poliester. Oleh karena itu, variasi fraksi volume $3 \%$ mempunyai kekuatan tarik yang tertinggi dengan modulus elastisitas sebesar 1027,523 MPa. 


\section{DAFTAR PUSTAKA}

Hul, Derek. 1981. An Introduction To Composite Material. Cambridge University Press. Cambridge

Isroful. 2009. Impact Komposit Serat Kenaf Acak-Polyester. Unnes. Semarang

Moncrieff, R.W. 1983. Struktur Dan Sifat Serat - Serat. Terjemahan Rosima Samah. Jakarta: Djambatan

Schwartz, M.M. 1984. Composite Materials Handbook. United States Of America: Mc.Graw - Hill BookCompany

Sinuhaji, Ferdian. 1994. Pengarah Tata Letak Serat Terhadap Uji Tarik Pada Komposit Ortropik Yang Dibuat Dari Poliester - Serat Kenaf. Medan: Univertas Sumatera Utara.

Supriadi, Tjahyono.1997. Pengaruh Serat Nabati Dan Fraksi Volume Serat Terhadap Sifat Mekanik Material Komposit. Jurusan teknik mesin FTI - ITS 